\title{
Post-Socialist Financial Fragility: the Case of Albania*
}

\section{Dirk J. Bezemer}

Tinbergen Institute and University of Amsterdam

\section{Roetersstraat 11}

1018 WB Amsterdam

The 1997 collapse of the Albanian economy caused by the collapse of economy-wide Ponzi schemes contrasts sharply to its success status as a post-socialist transition country in the years 1992-1996. In this paper, an attempt is made to explain this 'Albanian Paradox'. The specific Albanian conditions for the growth of Ponzi schemes are identified. Theoretically, the Albanian Paradox can be interpreted as one version of the 'Financial Instability Hypothesis' suggested by Minsky. Investigation of the underlying factors that render financial markets fragile suggests that the Albanian case is extreme but not rare in the region. In the post-socialist setting, expectations of the population and other potential investors based on a lack of reliable information on returns may lead to excessive capital inflow. This trend is reinforced if governments are weak, and if transition policies rely largely on liberal financial market development, rapid privatisation and external capital inflows, facilitating the tendency to instability. Identification of this trend is hindered if policy makers and observers largely rely on macroeconomic indicators in monitoring the economy.

JEL classifications: E12, G18, O5, P27, P34 
"The transition in Albania is likely to be particularly akin to a laboratory experiment" Anders Åslund and Örjan Sjöberg, 1992

"For the moment, just assume Albania doesn't exist." Albanian newspaper Koha Jonë journalist, March 201997

\section{Introduction}

The aim of this paper is an analysis of economic policies applied in post-socialist Albania. Despite its modest size, the country caught world attention when the Albanian economy and society collapsed early in 1997. This breakdown was remarkable in the light of Albania's recent economic history. Following its profound economic reforms in 1992, the country had been celebrated in much of the literature on the economics of transition as the classic example of sound post-socialist economic policy in line with the 'Washington consensus' (Williamson, 1994). By mid-1993, it could be claimed of Albania that is was the only country in Central and Eastern Europe that met every IMF-criterion. In the years 1992-1996 Albania initiated the most free market policies in Europe, and was considered a model country and a master student of international institutions (Hall, 1994, p. 276; McAdams, 1997; Albanews, 1997; Lyle, 1997). Such praise was justified by reference to Albania's macroeconomic indicators. In the years 1993-1996, inflation was contained, GDP increased, and unemployment decreased considerably.

These trends could be applauded right until the shock of early 1997. Ponzi schemes had been operating in Albania for some time on an ever increasing scale, and their collapse dragged the country within weeks into anarchy, widespread violence, plundering, and food shortages. The popular perception of this event was surprising from an analytical point of view. While Albania's IMF-inspired economic reform policies had been extensively credited for its exemplary post- 
socialist performance, the sudden collapse of its economy was viewed as merely a result of 'Albanians' mistaken notion of capitalism' (Wall Street Journal, March 24 1997).

In the present paper, an attempt will be made to challenge that explanation. Its point of departure is what could be called the Albanian Paradox: the curious fact that a post-socialist country could implement the standard transition 'package' with unrivalled adherence to the prescribed policies and show an outstanding macroeconomic performance - and simultaneously move ever closer towards collapse. Both its policies and its performance were at the extreme end of the spectrum of Eastern European transition experiences. Albania might therefore, as the quote at the start of this paper suggests, present an instructive case, if not a 'laboratory experiment'. The focus in explaining the Albanian paradox is on the nature of financial markets in transition economies from a Post-Keynesian perspective. The argument is that the high incidence of Ponzi schemes and other financial-market aberrations in the region was no mere idiosyncrasy, but inadvertedly fostered by the combination of restrictive monetary policies, a lack of market regulation, large capital inflows, and weak governments. These features have indeed been, to varying extends, typical of transition economies.

\section{Albania in Transformation: Policies and Performance ${ }^{1}$}

Albania, the smallest and least developed of the Eastern European transition countries, is located by the Adriatic Sea, bordering on Greece to the south, Macedonia to the East and rump Yugoslavia to the north. It has a 3,2 million population, $56 \%$ of which is employed in agriculture.

Albanian post-socialist history commenced in early 1992, when the first 'free and fair' elections were won by the Democratic Party, the one substantial opposition group to the exMarxist-Leninist Labour Party. The previous 48 years of socialist rule under Enver Hoxha and (since 1985) Ramiz Alia had isolated the country in every respect, keeping its standard of living the lowest in Europe. Late compared to other countries in the region, Albania in 1991 entered the 
international community when it joined the Conference on Security and Co-operation in Europe, the European Bank for Reconstruction and Development, the World Bank group and the International Monetary Fund, among others. Hesitant reforms, introduced in 1991, were reinforced politically in 1992 as Democrat leader Salih Berisha succeeded Alia as President and formed a new government.

Drastic economic reform was seen as inevitable as Albania found itself in the trough of recession, with a rapidly contracting economy, waves of poverty-induced emigration, a third of consumption coming from humanitarian aid, nearly a third of the labour force unemployed, a budget deficit of half the GDP, and inflation peaking to 45 per cent monthly in August 1992 (see table one for more figures). In mid-1992, the government introduced IMF-advised wide-ranging reforms. These included the liberalisation of price controls and of trade, tight fiscal and monetary policies and, starting July 1992, a floating exchange rate. Agricultural land was completely privatised, as were many small and medium-sized industries. With the introduction of unemployment benefits and pensions a social safety net was installed. With the commercialisation of various specialised state bank branches a two-tier banking system was established. The Albanian currency, the Lek, was made internally convertible, and brought into line with black market exchange rates, depreciating from 50 to 110 to the US Dollar.

By the end of 1992, macroeconomic circumstances stabilised. Microeconomic restructuring by then also began to show results. The number of private businesses in the capital had increased from just 398 in March 1991 to 8,321 in December 1992. Tax revenues, which had fallen from 42 per cent of GDP in 1990 to 28 per cent in 1991, began to rise in Tirana District by the end of 1992, signalling both an increase in private sector activity and the start of functioning of the tax administration, upon which the government now depended for revenues. With World Bank support, the government started the preparations for privatising 30 weak and large state enterprises. At the start of 1993, many economists read the beginning of an economic recovery in the main 
economic indicators. In the subsequent four years, this recovery continued. Albanian GDP rose dramatically (although from a very low base), official unemployment nearly halved, inflation was brought to single-digit levels, and foreign direct investment came in (see table 1).

\section{Table 1}

The break in these positive trends came in February-March 1997. Ponzi ${ }^{2}$ (or pyramid) schemes had been operating on an ever larger scale since 1992 (Albanews, 1997). In February they collapsed, swallowing a large share of the population's savings. Social unrest spread rapidly as masses of demonstrating Albanians demanded compensation from the government and strong suspicions existed about its involvement in the schemes. These protests, six weeks of looting, the plundering of army arms depots and the emergence of irregular, armed bands caused the government to loose control over the larger part of Albanian territory. The ex-socialist political opposition joined in and politicised rebel demands.

A wave of refugees attempted to flee, mainly to Italy. In response to the unrest, PM Aleksandr Meksi was replaced by Bashkim Fino. President Berisha, staying in office despite widespread misgivings, invited a World Bank/IMF team in order to investigate the Ponzi schemes issue and help restructuring the banking sector. In April, Albania's dismal situation led EU leaders to discuss the formation of a military intervention force. This 6,000 Italian-led force arrived in midApril to carry out 'Operation Alba', designed to assist in humanitarian aid operations. In early July, election results - dubious but accepted - brought the Socialist Party (formerly the Labour Party) to power again. A new Parliament was formed, and Rexhep Mejdani succeeded Berisha as President. Peacekeeper forces started leaving the country and new economic reforms, especially in the privatisation process and the banking sector, were initiated. In 1997-1998, Albania suffered heavily from the aftermath of the crisis. Significant parts of Albanian territory remain controlled by 
irregular, armed bands, the economy shrank to a level unprecedented in a decade, the incidence of random violence increased, and poverty rose dramatically.

\section{Reconstructing the $\mathrm{Crisis}^{3}$}

Obtaining and assessing the relevant information on the Ponzi crisis is problematic because of the informal and politically sensitive nature of the development and collapse of Albanian Ponzi schemes. A reconstructing of the Ponzi period, however, suggests that schemes could prosper through a combination of circumstances: restrictive monetary policies, large capital inflows, and financial-market policies that were very strict for official banks but extremely lenient for informal financial intermediaries.

\section{Prelude}

In the period from mid until end 1992, the economy was stabilised and inflation decreased dramatically. The main objectives of the financial system reforms in 1992-1996 included inflation monitoring, minimisation of the budget deficit, a solution to the foreign debt problem, and the creation of a two-tier banking system. In order to realise these priorities, the Bank of Albania committed itself to restrictive monetary and fiscal policies. Over the years 1992-1995, these included a considerable decline in official credit expansion and in government expenditures and broad money relative to GDP (table 2). In addition, reform policies limited the emergence of officially recognised financial intermediaries in several ways, facilitating the rise of an informal financial sector.

First, there were few official banks because of the strict requirements for the founding of banks in Albania. Except for a few former branches of the state bank and an Italo-Albanian bank (which did not engage in lending, only in administering a payment system), no licenses were granted to Albanians wishing to set up a bank, since 'no one showed the financial capacity to sustain a private bank' (ACER, 1996). Another potential capital source, the Tirana stock exchange, 
did not open until May 1996, and then proved unable to attract capital for business growth. Second, the banks that did operate were severely handicapped in two ways: both the defective payment system and the 'bad loan' problem left official banks with too little liquidity for adequate lending. Third, strict monetary and budgetary policies limited the official supply of money to the economy. Enterprise subsidies decreased from 16 to $2 \%$ of GDP in 1992-1993 and tight credit control on public enterprises was introduced in 1992. Broad money growth decreased from a high of $182 \%$ p.a. in early 1992 to less than $45 \%$ p.a. in 1994. Between early 1992 and mid 1993, real wages decreased by $26.6 \%$-increasing by only around $4 \%$ annually in 1994 and 1995-, while public sector employment decreased by two thirds (Haderi et al., 1999, p 131,133). Table 2 shows the impact of tight monetary and fiscal policies and prudent bank legislation in 1990-1995.

Table 2

While all this was very effective in containing inflation, official money market operations were thus limited to the point where this came to be a main constraint on the mobilisation of savings for investments and for growth of productive activities (Sadiraj, 1999, p 45) as official nominal interest remained far below inflation levels until 1995 (see table 5 below). In the absence of well-developed stock and real estate markets, this induced people and firms to revert to transactions on informal markets. The demand for financial intermediaries was especially large because of a considerable cash flow to the population in the transition years, which came from three sources.

The first was the Albanian workforce abroad, mainly in Italy and Greece. They numbered $300-400$ thousand in the years $1992-96$, which is over $10 \%$ of the domestic population, or about $15 \%$ of the labour force. Income from remittances amounted to $15-20 \%$ of annual GDP in 19921996, totalling an estimated US\$ 1 billion in these years (Mancellari et al., 1996, p 478; Elbirt, 1997; Frank and King, 1997; Albanian Times, December 1996: Lyle, 1997; Haderi et al, 1999, p 
134). The second source of inflow was the blockade imposed on the warring Yugoslav successor states by the international community, which created opportunities for lucrative smuggling, mainly of fuel and cigarettes, for the Albanian neighbours. Third, over half the 1992 GDP and about a third of 1996 budget revenues was provided by various foreign sources. Albania received the highest per capita level of EU aid of any East European state in this period (Lyle, 1997). Although much of it was provided in the form of food and commodity aid, there still was a large positive effect on savings (McNeilly and Schiesser-Gachnang, 1998, p 22). Table 3 presents details from the current account in the years 1992-1995 that indicate the relevance of foreign investments, emigrant wages and aid inflow relative to GDP. Note that this excludes illegal, possible sizeable, inflows.

Table 3

As a result, household savings rose from virtually zero in the last pre-reform year to US\$ 350 million in 1995, US\$ 600 million in 1996 and US\$ 700 million in 1997 (Elbirt, 1997). Meanwhile, both access to investment credit for firms and access to deposit accounts for the population were severely constrained in the official market. These circumstances drove first business people, later many more non-entrepreneur citizens to the informal markets, where Ponzi-like firms and foundations had started to operate.

\section{Ponzi Schemes: Strategies and Environment}

Among the first schemes were the prominent Albanian company 'Vefa' and the foundation 'Sude', which both reportedly started banking with Ponzi methods in 1992. The schemes operated earliest and mainly in the south-west of Albania, which is the region where most emigrant workers come from, and which generated the largest per capital emigrant wage inflow. It is also the area where later protests were most violent and which long remained incompletely controlled 
by central authority. Table 4 presents some of the features of these and other organisations running Ponzi schemes.

Table 4

This informal financial sector was not considered problematic by the economic authorities. The money-borrowing firms did not have to report on their sources of capital, and loans were not recorded in their balance sheets. They could use the accounts of the official Savings Bank and National Commercial Bank to place and withdraw their deposits without any account monitoring. Their loans were considered to sustain normal business activities, and were, in a February 1996 publication of the Albanian Center for Economic Research, mentioned neutrally as 'mutual agreements between the borrower and lender', as provided for in the new Civil Code. Hence, these transactions were subject to the Civil Code rather than to the strict banking law, and licensing was not required (Elbirt, 1997). The banking activities of, notably, the well-known firms 'Vefa' and 'Gjallica' were interpreted as conducive to the mobilisation of savings for investment in ex-state properties (ACER, 1996).

This view was partly justified: these firms, in contrast to schemes presenting themselves as 'charity foundations', made up for a sizeable part of the Albanian economy. 'Vefa' undertook business in trade, tourism, transport and food processing. It operated more than 200 businesses and employed 10,000 people. The 'Vefa' and 'Gjallica' organisations acquired real assets in Albania. Likewise, 'Kamberri' operated in agriculture, food processing and tourism and 'Gjallica' owned enterprises in trade, medicine and tourism. In addition, also the 'foundations' carried out some real investments, financing the construction of supermarkets, office complexes and gas stations. Over the years 1992-1996, productive activities were increasingly funded by 'Ponzi money' (Elbirt, 1997; McAdams, 1997, Albanews, February 28, 1997). 
The main advantage that Ponzi schemes offered to savers was, naturally, high interest rates. In late-1996 Albania, the reported 'profit' was up to 50 per cent monthly (Albanian Times, December 1997). Interest rates differed widely between funds. In consequence of the more extensive real sector activities of the companies, the interest rate they paid was 'only' eight per cent monthly, in contrast to the 60 per cent of, for example, the 'Populli Foundation' scheme. Table 5 compares formal to informal (probably Ponzi) interest rates in the 'Ponzi period', demonstrating that the latter were indeed the only agents that could offer attractive interest rates, given the high inflation in the early transition years; and also that the nominal interest they offered decreased as inflation was contained over time.

Table 5

In addition to offering high interest rates, Ponzi firms and foundations employed effective marketing and advertising strategies with full use of the state television (Nivat, 1997), extracting much of Albanian household money from under the proverbial mattress: starting 1993, a shift from consumption to savings occurred (McNeilly and Schiesser-Gachnang, 1998, p 22). Importantly, the absence of warnings from the government, the frequent appearance of pyramid managers and government officials side by side at public meetings and on television, and the association of pyramid managers with the Democratic Party lent state credibility to the schemes. Not only much of the population's savings and (domestic and external) income were 'invested', also many people took loans and mortgages on their house or land in the expectation of quick gains. As a result, by the last quarter of 1996, the schemes had accumulated more than US\$ 250 million in their accounts, a sum representing only $40 \%$ of their liabilities. By early 1997, the total value of received deposits reached US\$ 1.2 billion, or $50 \%$ of GDP, excluding accrued interest at the time of estimation (Elbirt, 1997). 
The long period (and hence large size) of Ponzi operations turned the detrimental sideeffects of schemes into threats to the economic system even while the schemes were operating. Given an average monthly salary of US\$ 70 in 1997, astronomical Ponzi gains competed with wage income. One interviewed entrepreneur in a few months time saw his work force of 130 slip to just 70. Another cost was that money that could have been invested in sustainable growth was now swallowed by the funds (McAdams, 1997; Frank and King, 1997; Financial Times, 1997).

\section{Collapse}

The end to large-scale Ponzi operations came in January-February 1997. In the last quarter of 1996, interest rates had risen from 30 to $50 \%$ monthly, with some foundations offering $100 \%$ monthly. By October 1996, the IMF had realised the dangerous proportions that Ponzi schemes had assumed, and warned the government against them, as the World Bank had been doing publicly since mid-1996 and earlier in government circles (Albanian Times, 1997; Reuter, 1997; Elbirt, 1997). On January 10, the National Bank of Albania under IMF pressure ruled that the 'money firms' were limited to daily withdrawals of US\$ 300,000 from their official accounts. Funds protested, claiming that they could only meet interest but not principal claims under this condition (ACER, 1996).

In the next week, first 'Gjallica', then the smaller fund 'Sude' set dates to repay principal, but failed to do so. At January 18, the 'Sude' top manager was jailed. 'Vefa' and 'Kamberri' announced they would stop repaying principal for the next 3 to 6 months. At January 19, public disorder broke out in Tirana, which was subdued by the police. The government froze the foundations' bank accounts. 'Xhafferri' and 'Populli' turned out to have a total of 25 billion Leks (US\$ 250 million). Open protests in the south started on January 21 in Shkodër, and spread to other cities in the subsequent days. On January 22, the public prosecutor announced that 'Xhafferri' and 'Populli' were Ponzi schemes, and their presidents were jailed. The presidents of 'Vefa' and 'Kamberri' were 
interrogated by the police. One 'Gjallica' president was imprisoned on February 7, another fled Albania. On February 5 and 6, these companies were also labelled Ponzi schemes. Meanwhile the Savings Bank had started to distribute what was left of the funds of former 'Populli' investors, while protests spread further through the south and turned into uncontrolled violence. In April, more than a hundred government officials were sued for using their position to foster the schemes for private enrichment. Over 1997 and 1998, a total of 17 schemes were dismantled or (if they were owned by companies like Vefa) monitored by auditing firms, and part of their assets sold (Albanews, 1997, 1998). The crisis brought down the President and the government, and induced new reform policies, with a focus on the financial sector.

Causes

Although many economies have Ponzi schemes, nowhere else were they observed to crush the economy and temporarily dissolve society as they did in Albania. Among the features of the Albanian experience described above, the following can be identified as specific causes for the dramatic impact of Albanian schemes.

First, instead of fighting Ponzi scheme operators, Albanian government officials lent state credibility to them. Second, a lack of political diversity in Albania precluded serious opposition to and checking of government members' self-enrichment. It also left foreign governments, the EU and monitoring institutions with no alternative political partner, a circumstance which increased the discretion of Albanian government officials. Third, a (partly 'black') money inflow into the schemes, large in relation to the size of the economy, and originating in smuggling gains, emigrant wages and foreign aid, allowed schemes to connect their fate to that of the economy, and drew a large fraction of the domestic population into the schemes. Fourth, the explicit informalisation of financial markets allowed 'money firms' and 'foundations' of every sort to start and operate without requirements (e.g. concerning management, capital reserve or investment strategy). The striking contrast is 
that, while the authorities imposed very strict conditions on growth of the official financial sector, there were no regulatory impediments for those 'banking' with Ponzi methods.

Two additional impacts of the Albanian schemes on the economic system relate not to their functioning, but to their collapse. The schemes did not die with a whimper, but collapsed suddenly. There was little effort by or opportunity for operators to protract their functioning; this caused maximal redistribution and impoverishment. Finally, the political consequences (anarchy and random violence) of the Ponzi collapse were caused by the already polarised political scene and the ready availability of arms in the many army depots throughout the country - an inheritance resulting from Hoxha's fear of a foreign invasion. The Ponzi problems were eagerly exploited by the exsocialist opposition to win the population's support. It supported rebel claims for a 'political solution' to the problems, i.e. the removal of Berisha as President and new elections (McAdams, 1997). These circumstances allowed a sudden and widespread economic problem to turn quickly into a political and (almost immediately) also a physical, territorial battle.

\section{The Welfare Effect}

The economic impact of the Ponzi period on the Albanian economy was certainly large and disastrous, but inherently difficult to estimate. Direct indications of the welfare effects of the episode include 1500 victims of the continuing violence (as of February 1998), much material damage during the protests, a large amount of savings and income lost, and serious reductions in income and employment. The share of the population involved at the moment of collapse is estimated at between one sixth and one half. Estimates of the amount of money swallowed by the schemes run between 300 million, 0.5 billion, 1.2 and 1.5 billion US Dollars. The latest figure, 1.2 billion Dollar, is roughly equal to total wage remittances from overseas in 19931996, or to half the average annual GDP in those years. The figures on the volumes of schemes are, however, problematic both because of the informal nature of schemes and 
because people tended to include the virtual interest on their money in reported losses. Only an insignificant part of investments (11 million US Dollars as of June 1997) has been returned (Gomez, 1997; McAdams, 1997; Albanews, 1997; World Bank, 1997). Hence, the longer run impacts of the Ponzi period include the burden of debts, mortgages and loss of jobs that many citizens will have to cope with.

As a direct consequence of the crisis, the Lek depreciated by $25 \%$ to the US dollar over the first six weeks of 1997. GDP decreased by around $10 \%$ through 1997 and the annual rate of inflation shot up from $13 \%$ to over $40 \%$, averaging $32 \%$ in 1997. 150,000 families were newly registered for unemployment assistance between March and August 1997, and the average monthly income of the unemployed sank to US\$18. After the collapse, urban and rural pensioners received US\$ 25 and US\$ 8 monthly, respectively, while the corresponding incomes for 1996 had been US\$ 38 and US\$ 10 (Albanews, 1998). The observation that Albania, after four years of seeming growth and the Ponzi crisis, 'was shrinking to less than its size in 1990' (Lyle, 1997) seems entirely plausible. Most important, if trust is the major asset of an economic system, Albania has a huge liability to pay.

Crucial to the real-sector impacts of the financial crisis are the large opportunity costs that Ponzi schemes have: they immobilise money that could have been used (more) productively. In the extreme, capital inflows in a Ponzi-dominated economy have no effect on welfare, but merely increase the amount of money in circulation, driving up nominal wages and prices at constant real incomes. In contrast, increases in real welfare can be realised either through domestic production or through imports. One important question therefore is: how did the presence of Ponzi schemes in Albania affect investments, trade and real incomes?

Ponzi money is typically concentrated in the hands of a few. This reduces both investments and demand. Much of Ponzi money is likely to be channelled to foreign bank accounts or consumed, given the short time horizon of Ponzi operators, while also domestic money will 
translate into low effective demand if held in concentrated ownership. Still, the Albanian Ponzi schemes had limited but positive spin-offs as some of the largest were managed by domestic firms which were active in business, trade, and (marginally) in production.

However, what growth in welfare was achieved in 1991-1996 in Albania derived mainly from imports, largely financed with the sizeable capital inflows of the period rather than by increased exports. One obvious setback of such growth is that it is inherently temporary: welfare will fall as soon as cash inflows and related imports cease. There is growth but not development. Table 6 shows the trade balance for these years, indicating the divergence between exports and imports.

Table 6

In line with this observation, the welfare level as measured by real wages did not change materially. IMF data show that while indexed nominal wages rose from 100 in the base month December 1990 to over 6500 index points in January 1996, real wages remained roughly stable during the whole period. Also analysis by Sadiraj (1999, p 47) indicates that Albanian growth consisted of 'level changes rather than productivity increases'. Together with the depicted decline in exports, the apparently voluntary decrease in employment during the Ponzi period reported in casual observation (Frank and King, 1997) and the sharp increase in unemployment after the collapse, this suggests that increased imports may have balanced a decreasing share of domestic production in GDP. In this interpretation, Ponzi schemes damaged the economy in two ways. Not only did they facilitate imports at the cost of domestic production while in operation, they also implied a blow to the real sector when 'financial markets' collapsed because of the increasing dependence of what domestic production there was on Ponzi finance. 


\section{The Albanian Paradox Reconsidered}

The theoretical problem posed by the 'Albanian paradox' is how an economy could seem sound in terms of macroeconomic figures (GDP, unemployment, inflation and budget balance), while moving ever closer towards serious distress or collapse. That definition of the problem is actually relevant to more Central and Eastern European countries than Albania only. Albania was the only national economy in the region to suffer so seriously from Ponzi schemes; but Ponzi schemes were prominent features of most Central and Eastern European economies for some time during the 1992-1996 period. This suggests that they were no mere idiosyncrasies, but rather a result of the one common factor of these economic systems: their post-socialist reform situation and policies.

\section{Ponzi Finance in Eastern Europe}

Verdery (1996, p 169) reports schemes in the Czech Republic, Slovakia, Bulgaria, and former Yugoslavia (notably Serbia). Most prominently, 'Caritas' in Romania and 'MMM' in Russia became conspicuous parts of the respective economies.

Caritas, opened in April 1992, reached its heyday in the autumn of 1993. According to the most frequent estimate, 4 million Romanians, or roughly 20 per cent of the population, deposited money. Caritas is said to have handled 1.4 trillion Lei altogether (compared to 1993 government expenditures of 6.6 trillion Lei). In autumn 1993 it held a third of the country's banknotes. After over one and a half year of operations, Caritas collapsed in early 1994 - but slowly, since its initiator attempted to restructure the fund, meanwhile continuing to pay obligations. Caritas did not fall, but died with a whimper, a circumstance that decreased investor's losses considerably, and softened the destructive impact of the collapse of this scheme (Verdery, 1996, p 168-204).

The Russian fund 'MMM' was set up in the early transition years. In its initial year of operation, MMM managed to attract 5 million investors. It advertised on television with share prices increasing twice every week, and MMM shares were traded in the stock market. When the 
scheme collapsed in the summer of 1994, its 'share price' fell from US\$ 62 to US\$ 0.50 within one week. MMM was the largest, but not the only scheme operating in the Russian economy. The collapse of other 'investment companies' like Tibet, Ruski Dom Selenga, and Khopor Invest resulted in many more millions of Russians losing their money (Spicer, 1996; Federal Commission, 1996).

The final disfunctioning of the Albanian funds had even more destructive impacts, for reasons given above. If the high incidence of Ponzi schemes in transitional countries suggest a common, systemic background, they are not to be viewed as idiosyncratic hypes, but as symptoms of specific shortcomings in the financial side of the economic system in transition countries. In this view, Albania is the extreme, and thus instructive, case for analysing non-sustainable financial market developments in the region.

Theoretically, the interesting issue is why such non-sustainable developments were not halted, not how financial market instability and seeming macroeconomic success could combine. The latter question can be answered straightforwardly by inspecting the definition of the relevant variables - unemployment, inflation, GDP, budget deficit and exchange rate. Given substantial capital inflows, there is financial room for stable or rising employment. Inflow of foreign currencies may also sustain the domestic money base and finance the imports necessary to realise a real welfare increase as well as the wages that provide the matching purchasing power. Moreover, as GDP measures the value added in both the financial and real sector, GDP figures rise even if the boom in financial markets has no spill-over effects in the real sector. Since GDP growth increases the tax base, while none of the above developments in themselves necessitate large government spending, the budget deficit may be sustainable or actually decrease. All this was realised in 19911996 in Albania, as shown in table 1.

This accounting perspective, as mentioned, leaves unanswered a number of questions as to the why of financial market deformations in transition countries. Why did the authorities not 
recognise the danger in time, or in any case not implement policies designed to halt scheme growth? Why did the population participate on a large scale? At issue here is how the economic system is perceived both by policy makers and economic agents, how that information is processed, and what actions follow. The theoretical perspective on financial market instability developed by Minsky (1972, 1977, 1978, 1980, 1982a,b) is helpful at this point.

\section{The Financial Fragility Hypothesis}

Ponzi schemes are located at the extreme end of a spectrum of financial markets, classified according to their 'fragility' (Minsky,1978). Fragile financial markets are prone to a non-sustainable boom, ending in financial distress or even a recession. The explanation of that periodic instability in financial markets builds on Keynes' notion of money as a financing 'veil' between the real asset and the wealth owner, which explains why capitalist economies are 'so given to fluctuations' (Keynes, 1952 ed., p 169). In this view, the monetised economy is inherently dynamic, since the key economic transaction is the exchange of money today (current goods) for money tomorrow (financial assets).

Financial commitments on capital markets reflects such transactions, and have to be made in the face of intractable uncertainty (as opposed to calculable risks). This implies that views about the future can undergo marked changes in short periods of time, generating instability (Minsky, 1977, p 60,62; 1978, p 102). At any point in time, commitments break down into three categories. First, 'hedge finance' includes assets with cash flow revenues equal to or larger than cash flow commitments in both the short and long run. Second, capital assets held in 'speculative finance' have short-term cash flow revenues that fall short of short-term commitments. These are met instead by rolling over or refinancing debts in the expectation that long-run revenues will be large enough to meet outstanding commitments. This is typical for banking activities. Third, 'Ponzi finance' assets are characterised by cash flow commitments that are larger than cash flow revenues in both the 
long and short run, and hence need perpetual rolling over, which is naturally not sustainable. Over time, the market share of speculative and Ponzi finance tends to rise through a shift in risk preferences due to a gradual decrease in the value of insurance that the holding of money provides. A consequent shift in portfolios towards the more rewarding, and more risky modes of speculative and Ponzi finance sets off a boom.

During the boom, expectations grow optimistic to the point of euphoria. (An economy that is ruled by expectations of perpetual expansion is characterised as euphoric.) Hence, lenders accept assets that would previously have been (risk-corrected) low-yield. The demand for money can be met either by an increase in the money quantity by the monetary authorities, or by banks' money creation, which will be larger as financial markets are more sophisticated. As these are both limited sources, financing needs inevitably raise interest rates, lowering the value of long-term debt. When this fall initiates doubts on the validity of euphorical expectations, a reconsideration of investment programs occurs and portfolios are hedged. This as well as the inelasticity of aggregate supply in the real sector yield a shortfall of the investing units below the more optimistic profitability levels of the euphoric expectations. The result is a combination of cash flow commitments from the burst of euphoria and of cash flow receipts based on lower-than-expected income: an untenable debt structure.

Depending on the dominance of Ponzi/speculative finance and on financial policies, the unwinding of euphoria may occur with little trouble, and a new boom may be entered; but it may also involve financial instability, and become the source of deep depression and stagnation. Financial crisis occurs if units need or desire more cash than is available from their usual sources and resort to unusual ways to raise cash, such as liquidating positions. To the extent that businesses are funded by financial assets, every position on the financial market that is liquidated cuts off businesses in the real sector from investment channels. Thus financial instability may cause serious declines in production and employment. 


\section{Post-Socialist Financial Instability}

Before applying this model of financial fragility to the nature of Ponzi finance in Central and Eastern Europe, its relevance should be considered. The model includes assumptions on the financial system, the nature of the real sector in the economy and the stock market which originally characterised Western, not post-socialist countries. However, the similarities are more striking than the differences. Consider this claim in the Albanian context.

First, there was no sophisticated financial system, which is the type of economy Minsky writes about. This implies that it is not possible to finance investment in the short run by portfolio transformations in which money is created in the financial market independent of monetary policy; yet this is the motor of asset price increases. The alternative route, an exogenous increase in the quantity of money, is not part of the standard model. However, it modifies the model but not its results, as Minsky (1972, p 134) points out. This route was taken in the Albanian money market. Investment opportunities largely depended on cash inflow in the national market rather than money creation by intermediaries. In addition, after the initial stage of establishment the schemes started to form a financial market of their own, where many citizens choose to create more 'money' by reinvesting astronomical gains on earlier investments. Both real and such 'virtual' money quantities increased dramatically, financing the continuing shift towards and increase in high-yield, high-risk Ponzi finance.

Second, there was no capital-intensive economy in the physical sense. In Minsky's account, physical capital generates instability by attracting money as investments in capital assets. These then become overvalued and precipitate financial crisis. However, insofar a break in the link between realised profits and financial commitments on capital assets generates an unsustainable debt structure, Albania fits the model: in the end, the expected return on Ponzi 'assets' fell inevitably short of available 'profits'. Money was not attracted to real investment opportunities but to Ponzi schemes which just made a pretence of investing money; but that did not alter the money 
accumulation mechanism from the perspective of the investor.

Third, the end to euphoria came not as a result of falling stock prices, but as a result of the announcement of the non-sustainable nature of schemes. This dissemination of information played the role that falling stock prices play in normal financial markets, spreading doubt about investment profitability and inducing a reconsideration of financial positions. In financial markets this means a portfolio shift to safer assets; in the Albanian setting it meant masses of citizens besieging banks and firms in order to get their money back.

Having argued the relevance of the model for post-socialist financial aberrations, it is also important to stress its systemic nature. After a crisis it will always be possible to construct plausible arguments -by emphasising the triggering effect or institutional flaws- that accidents, mistakes, or easily corrected shortcomings were responsible for the disaster (Minsky, 1972, p 118). The popular reaction to the Albanian crisis provides an example. In contrast, in the view elaborated above, instability is an inherent feature of the interplay of investment and financial intermediation, causing the self-destructive tendency of financial tranquillity (Minsky 1978, p 111; 1972, p 144). Instability is driven by ever-changing expectations, which are controlled by the available information and the way it is processed. One extension of this approach therefore is to investigate the perception and processing of information and consequent actions by economic agents and policy makers in transition economies. In addition, it must be noted that this approach does not imply strict determinism with respect to the actual materialisation of potential instability or its real-welfare effects. Both can be influenced by policy and through the ability of institutions to modify the behaviour in the economy (Minsky, 1978, p 112).

Essential to the Minsky framework is also that there are common tendencies in all financial markets, be they Ponzi schemes or conventional stock markets. The difference is in the strength of the tendency to instability, not in the existence of that trend or in the mechanism by which it is generated. Hence, in the next section aberrations on post-socialist financial markets in general are 
considered, of which Ponzi schemes are the extreme, but not the only example.

\section{Information, Expectations, and Policy}

As an application of Minsky's model, three factors can be suggested which tended to foster unrealistic expectations on returns to financial assets, creating a climate in which market aberrations like Ponzi schemes could thrive. These are both related to the central role of expectations and information in financial markets and typical of the post-socialist setting.

\section{Experience, Expectations and Information}

The traditional view on the microeconomics of investment behaviour asserts that people invest in search for the highest risk-corrected pay-off. However, the risk-corrected profitability of Ponzi investments is negative for the larger part of participants. Crucial to understanding why a large share of the population participated in schemes nevertheless is therefore an account of how people asses profit and risk. Plausibly, the experience-based ability as well as the inclination of economic agents to assess pay-offs depend on the nature and history of the relevant economic system. After all, Ponzi schemes appear to offer huge gains. It takes calculation and, most of all, either experience or information on previous experiences to realise that such gains only materialise when the scheme lasts long enough, that they are made at the cost of others, that the chances of a breakdown during one's involvement are considerable, and that such collapse implies a total loss of the investment.

The habit of caution and calculation when dealing with financial intermediaries may be something that is acquired over time and by experience, as all habits are. It may therefore be a typical trait for economic agents in mature market economies, but not necessarily in post-socialist transition economies. Specific for the latter set of economies, especially in the early transition years, was people's trust in 'the market', fostered by hazy, and primarily rosy notions of what capitalism was. This misplaced trust was the breeding ground for schemes that Kindleberger (1978, pp 79-80) 
characterised as relying on 'misrepresentation or violation of an implicit or explicit trust'. Ponzi schemes fit perfectly into the misleading picture of capitalist countries, were "the streets are paved with gold and everyone is rich" (Verdery, 1996, p 176) - a perception of the new economic system that was only too general among the population in the early transition years, and one which may have dictated investment and risk-assessment norms for many citizens.

One indication of the relevance of this elusive factor is the fact that stories explaining the high and continuing profitability of schemes circulated widely wherever Ponzi schemes were prominent features of the economy, rationalising trust in the schemes. Characteristically, the Romanian Caritas success was commonly explained by profits made in private foreign trade, that novel symbol of capitalism. The unusual high 'interest rates' of Albanian schemes were explained by their operators as resulting from high profits from a Californian hotel, or from operating nonexistent mines. More spectacularly, the Albanian 'Sude' foundation was led by a woman who claimed to be able to forecast the financial future by looking into a crystal ball. Many investors took it. And when the schemes collapsed, many indeed were unaware of just how much they had lost (Gomez, 1997, p 2; Verdery, 1996, p 177; McAdams, 1997; Elbirt, 1997).

\section{The Role of the State}

In addition to expectations in the population, also the role of national policy makers facilitated financial market aberrations. In our example, it is not difficult to understand why Albanian policy makers did not intervene in informal financial markets while there was still scope to unwind the Ponzi crisis less dramatically. The evidence in the empirical section clearly points to government involvement and officials' profiting from Ponzi growth. In all probability they recognised the destructive impact of Ponzi schemes; but equally probably they had every private disincentive to discourage further growth. This is typical for all of the economies mentioned where Ponzi schemes assumed disruptive proportions. Given the importance of government action in the creation and 
enforcement of legislation and the dissemination of information concerning the destructive nature of Ponzi schemes (Verdery, 1996, p 270), the failure to intervene where necessary was a decisive factor. In general, the development of market aberrations was facilitated by the conditions of 'state desertion' or 'state collapse' that characterised post-socialist reforms (see e.g. Szekely and Newbery, 1993; Ellman, 1997).

Furthermore, in the absence of early and decisive action, Ponzi schemes are hard to contain. Once a scheme sets off, the government is soon beyond a point of no return even if it would want to combat scheme growth. The stakes that the population has in the schemes are then typically so high that effective government intervention grows too costly politically: schemes soon grow 'too big to fail'. Moreover, as Ponzi profits pervade society, local government will not be unaffected and may then be not only hardly able, but unwilling as well to act. The only effective signal that the central government can give at that point is allowing the scheme to tumble with much noise and losses - for example by sponsoring or setting up competing schemes, as the Romanian government did in 1993 in order to minimise political damage (Verdery, 1996, p 199). Active government encouragement from the beginning until almost the end, as in Albania, is the extreme case, and produces the extreme result.

An additional note on the role of government concerns the perception of pervasive government responsibility in post-socialist societies as a stimulating factor for schemes' operations. Even if people in Albania had doubts about the nature of the schemes, a general expectation, based on expereinces with pervasive state paternalism, was that the government would bail them out if anything went substantially wrong (Elbirt, 1997). The combination of the absence of structural regulation of financial markets and frequent $a d$ hoc interventions in financial crises has been a typical problem for post-socialist states. 


\section{Transition Policies}

Also economic policies in the transition years tended to facilitate the growth of Ponzi and speculative finance. Fragile financial market are likely to develop in countries that (1) aim at reforming their economic system rapidly, (2) with a stress on developing a market for financial assets at the cost of real-sector development, (3) which are able to attract sizeable capital inflows (investment, loans or aid) and (4) with monitoring almost exclusively directed towards macroeconomic variables. These were typical features of post-socialist economic policies. First, fast reforms, which have been the dominant option in the transition debate (e.g. Gros and Steinherr, 1995, p 98), often stress speed at the cost of institutional balance (McKinnon, 1992; Nuti, 1996; Tsang, 1996). This may lead to the creation of financial investment opportunities in the absence of palpable productivity increases in the real sector. A view on post-socialist restructuring in which financial intermediation is assigned a central role, as has been common (e.g. Gros and Steinherr, 1995, $\mathrm{p}$ 199), is conducive to the development of such disparity. This trend is reinforced if privatisation does not imply micro-economic restructuring (for which it allegedly is instrumental).

There is ample evidence that the relation between ownership and efficiency-enhancing restructuring was both a main reason for privatisation programmes in Central and Eastern Europe and proved problematic when they were implemented ${ }^{4}$. Nominal privatisation that does not lead to real restructuring and an increased efficiency may give the economy the false appearance of a decentralised model with good profit opportunities for the foreign investor. When, in contrast, restructuring incentives, efficiency increases and hence profit opportunities are much lower than investors and lenders are led to expect, sizeable capital inflows in investment, loans, or aid may be followed by disappointing performance, adjustment of expectations and a growth slowdown or recession along Minskyan lines.

Albanian reforms indeed facilitated a complete disparity between financial and real profit expectations, and resulted in the population investing in virtual projects, followed by collapse and 
crisis. That was the extreme case in the region. However, with the benefit of hindsight, the divergence between expected and real profits is observable in most of the economies that privatised their productive structures in comprehensive programmes. As one well-known illustration, the Czech experience was both the role model for other countries (among them Albania) and later led to disappointment regarding its effects. The 1991 voucher privatisation was, for some years, thought to have achieved a very decentralised, outsider-dominated, and hence efficiency enhancing ownership structure, and relatively large foreign investments boosted the Czech stock market in 1992-1997. It is now clear that this privatisation model in fact preserved economic power for an elite, as citizens' vouchers were bought on a large scale by a few so-called investment funds. These were largely owned by the four banks that dominated the financial sector, in which the government in turn had a controlling share. Between them, they managed $60 \%$ of the vouchers that represented ownership titles of the country's industrial firms, either directly or through investment funds. The large interdependence between the banking and industry sectors facilitated corruption and largely forestalled corporate restructuring and much of potential efficiency increases in the transformation period up till 1997. This resulted in a tumultuous restructuring operation which uncovered more ties between commercial banking, industry and the polity, resulting in a severe economic slowdown (Harris, 1997; Cook, 1997; Schwartz, 1997).

Although not all post-socialist countries implemented voucher privatisation, post-reform ownership-and-control structures are likely to create similar pressures since typically a few large banks cover most of the market for financial intermediation. The interlinkage of government, banking and industry prevents disciplining of the financial sector by the government and constitutes a disincentive for banks to discipline industry through corporate governance mechanisms. The result is pressure on the government for 'soft' budgets to industry and banking, little restructuring in industry, and inefficient credit allocation in the banking sector. In sum, typically the newly capitalist economic systems have been creating expectations that their systemic flaws made it very hard to 
live up to. In Minsky's terminology, it is plausible that much of capital inflow in the region was speculative rather than hedge finance, facilitating an unsustainable boom rather than longer-term productive investments.

\section{Macro Monitoring Deficient}

Taken together, the above factors do account for the growth of Ponzi schemes and other unsustainable financial structures in post-socialist reforming economies; but they do not explain why such aberrations often were not speedily detected. Given the identified weakness of governments typical for many post-socialist reforming economies, their lack of action, if perhaps not of perception, is understandable. Still, it is puzzling why warnings on the policy level did not come earlier and more effectively from the international institutions. Again, Albania provides a good illustration. Through the IMF and (to a lesser extend) the World Bank, the international community contributed significantly to Albania's growth in the Ponzi period. In line with conditionality requirements, both institutions were involved in and, as a consequence, extensively credited for Albania's apparently successful reform policies. Presumably, these institutions had some influence on economic policies. In any case, they were in a position to voice vocal concerns, as they did late in the Ponzi period. The question is why did they not detect Ponzi schemes earlier and advise policies that might have impeded further growth, or -if that was not an option- warned against schemes earlier than they did?

It may have been the particular way of monitoring the economy, with excessive attention to macro-economic (particularly monetary) indicators, which misled observers. It was shown for the Albanian case how Ponzi growth may leave macro-economic figures unaffected. In this respect, Albania is again extreme but not unique. If economic performance is monitored exclusively through observation of the macro-economic variables, the development of fragile financial markets may go unnoticed. Unfortunately, the economics of transition indeed seems to have suffered from a such a 
'dominant reductionist tendency of discussing reforms in terms of two or three key variables' as Aligica (1997, p 46) observes. Zecchini (1997, p 2) notes of transition policy designers that 'the focus of their policy strategies often shifted towards pursuing the elusive objective of macroeconomic balance'. Laski and Bhaduri (1997, pp 103-104) likewise lament 'the collapse of the communist economies and the drawing up of transition programmes in a period when economics was dominated by free market ideology'. Significantly, they note that ' $(\mathrm{t})$ hese ideas can perhaps find their best expression in the overall expression that by controlling the proper value of some crucial financial variables, especially a low budget deficit, low inflation and a stable exchange rate, the government can decisively influence the real economic variables'. Ellman (1997, p 28) in the same vein points out that 'neglect of the interrelationship between monetary and real variables' was one of the major weaknesses of 'shock therapy'.

\section{Summary, Discussion and Conclusions}

In this paper an empirical description of the 1997 Albanian crisis is provided, and its direct causes and effects are identified. Theoretically, the unsustainable Ponzi-boom is analysed in the framework of Minsky's Financial Fragility hypothesis, in which investors' expectations based on information and experience have a tendency to generate instability. For the Albanian example, it is shown that Ponzi schemes could prosper through a combination of circumstances: (1) expectations and experience of the population specific for the history of the economic system; (2) transition policies relying on restrictive monetary policies in the absence of substantial restructuring and investment opportunities, which may generate expectations of excessive returns on and large inflows of capital; (3) government involvement in rather than containment of the schemes, which was a deceptive credibility signal to the population; and (4) a focus on macroeconomic variables rather than the structure of the economic system in monitoring the economy, which may have caused observers to lose sight of the development of fragile financial structures such as Ponzi schemes. 
These features are, to varying degrees, typical for post-socialist transition economies in the region. Hence, several conclusions that are complementary and corrective to the early reform consensus follow straightforwardly. On the micro-economic level, the emergence of markets is based on the development of market-conform behaviour of economic agents, for whom previous experiences mould expectations and actions. Hence, fully-fledged markets cannot be installed but must mature. In that process, the quality of government and the quality of market information which guides investment behaviour are closely linked. On the macro-economic level, financial liberalisation may cause instability even when macroeconomic stabilisation has been achieved. Proper regulation (especially in financial markets) and governmental integrity are as essential to successful reforms resulting in sustainable growth as are traditional factors such as correct prices, healthy competition and private-sector development. Arguably, neglect of the role that financial markets have in post-socialist instability has been a main sequencing error in reforms.

Furthermore, voluminous capital inflows are not always a blessing, but can destabilise transforming (and developing) economies. With regard to the effect of such flows, the economic structures into which they are fed are more important than is their size; and in general, a characterisation of the economic system by macro-economic variables only is a poor monitoring tool. Finally, country-specific factors (such as the effect of the Albanian emigration on economic development) cannot be ignored in reform policies. All these points have by now been made repeatedly in other studies on reforming and emerging economies, both theoretical and empirical ${ }^{5}$. This paper provides another illustration of their validity, detailing the genesis of market aberrations and their effects in one specific case.

Although such observations are now no longer novel, neither are they superfluous. In the case of Albania, present analyses of previous policies still tend to disregard such adverse effects of earlier reforms. Financial fragility is not sufficiently captured by noting, without further specification, that "political stability and control of the informal financial sector are also crucial" or 
that "now is an opportunity to renew the momentum for reforms" (Hashi and Xhillari, 1999, p 100; Haderi et al, 1999). Typically, McNeilly and Schiesser-Gachnang (1998), investigating the 1992 inflation reduction policy in Albania, ascribe its success to trade liberalisation, extensive external assistance, tight fiscal policy, increased savings, and hard budget constraints - but fail to note the perverse effects on financial markets developments that these very policy instruments and their responses can have, and clearly had in Albania. With no attention to such factors it seems unwarranted to "hope that, following the devastating economic crisis Albania suffered in 1997, high inflation can again be quickly reduced and the basis created for sustained growth' (McNeilly and Schiesser-Gachnang, 1998, p 3). Future reform policies should rather be informed by the lessons from transition policy failures as well as by those from the successes.

Specifically, the above conclusions suggest the following policy recommendations. Reform programmes should focus on actual restructuring mechanisms rather than proceed from the assumption that restructuring incentives are fully implied in ownership structures. The involvement of financial intermediaries in enhancing the performance of the real sector in the economy is indispensable, but cannot be seen to replace the process of restructuring itself. Moreover, as the financial sector has a decisive role in the dissemination of information on profit opportunities to investors, the quality of that information can probably be improved by proper financial-sector regulation, rather than by a stress on liberalisation only. Regulation is also desirable because of the large effects on growth that perverse developments on financial markets can have, especially in the presence of sizeable capital flows. Finally, reform policies should take into account the constructive role that the state must have in market development if it is to succeed. 


\section{Footnotes}

* University of Amsterdam and Tinbergen Institute. All errors and opinions are mine, but I thank Michael Ellman, Klara Gerxhani, Ruud Knaack, Luc Moers, Milo Petraq, Klarita Sadiraj, participants at a conference at the University of Birmingham, and three anonymous referees for helpful discussions and corrections.

1. Based on Albanews (1997, 1998), Albanian Times (1997), Aslund and Sjoberg (1992), Blejer et al. (1992), Commission (1994), Elbirt (1997), EBRD (1997), Frank and King (1997), Haderi et al. (1999), Hall (1994), Hashi and Xhillari (1999), OECD (1996), OMRI (1997), Pashko (1993), Reuter (1997).

2. 'Ponzi finance' can be defined as 'a situation in which cash payments on debts are met by increasing the amount of debt outstanding' (Minsky, 1982b:67). In standard modelling terms, that is only feasible when either the population is infinite or individuals are uninformed and/or irrational (O'Connor and Zeldes, 1992:147).

3. Based on ACER (1996), World Bank (1997).

4. See Bolton and Roland (1992), Aghion (1993), and Aghion et al (1994), among others, for initial expectations. For actual outcomes in Central and Eastern Europe, see Earle and Tegdely (1998) for Romania, Carlin et al. (1995) and Bornstein (1999) for Poland, Hungary, and the Czech and Slovak Republics, Djankov and Pohl (1998) for the Slovak Republic,and Marcincin and Van Wijnbergen (1997) for the Czech Republic.

5. On capital flows to transition countries, see Schönfelder (1996) and Calvo, Sahay and Vegh (1995). On financial liberalisation and instability, see Nuti and Portes (1993), Arestis and Demetriades (1993) and Demirguc-Kunt and Detragiache (1998), among many others. See also EBRD (1998) for an overview of cross-border capital flows and the financial sector in transition. 


\section{Bibliography}

ACER 1996. The Informal Financial Sector. Working paper prepared for the AUB Workshop, February 29 March 2, 1996. Preliminary draft. Tirana: Albanian Center for Economic Research

Aghion, P. 1993. Economic Reform in Eastern Europe: Can Theory Help? European Economic Review, vol. 37 , no. $2,525-532$

Aghion, P., Blanchard, O. and Carlin, W. 1994. The Economics of Enterprise Restructuring in Central and Eastern Europe. CEPR Discussion Paper Series, no. 1,058, London

Albanews 1997. Foreign Media/ Reaction Daily Digest. Internet address:

http://listserv.acsu.buffalo.edu/archives/albanews.html

Albanian Times 1997. "Pyramid Schemes Worry IMF". Albanian Times on Internet, December Issue. Internet address: http://ww.worldweb,net/ ww1054/times/12_17_96.html\#ban

Aligica, P. 1997. The Institutionalists' Take on Transition. Transition (published by the Open Media Research Institute), vol. 3 , no. 5, 46-49

Arestis, P. and Demetriades, P. 1993. Financial Liberalisation and Economic Development: A Critical Exposition. In: Arestis, P. (ed.) Money and banking: Issues for the twenty-first century: Essays in honour of Stephen F. Frowen, second edition. New York: St. Martin's Press, London: Macmillan Press Åslund, A. and Sjöberg, O 1992. Privatisation and Transition to a Market Economy in Albania. Communist Economies and Economic Transformation, vol. 4, no. 1, 135-150

Blejer, M., Mecagni, M. Sahay, R. Hides, R. Johnston, B. Nagy, P. and Pepper, R. 1992. Albania: From Isolation Towards Reform. IMF Occasional Paper no. 98. Washington DC: IMF

Bolton, P. and Roland, G. 1992. Privatization Policies in Central and Eastern Europe. Economic Policy, vol.7, no. $15,275-303$

Bornstein, M. 1999. Framework Issues in the Privatisation Strategies of the Czech Republic, Hungary and Poland. Communist Economies and Economic Transformation, vol. 11, no. 1

Calvo, R. Sahay, R. and Vegh, C. 1995. Capital Flows in Central and Eastern Europe: Evidence and Policy Options. International Monetary Fund Working Paper 95/57

Carlin, W., Van Rheenen, J and Wolfe, T. 1995. Enterprise Restructuring in Early Transition: the Case Study Evidence from Central and Eastern Europe. Economics of Transition, vol. 3, no. 4, 427-458 
Commission on Security and Cooperation in Europe 1994. Human Rights and Democratization in Albania.

Implementation of the Helsinki Accords. Washington DC: CSCE

Cook, D. 1997. Fool's Paradise. Business Central Europe, April issue, 17-18

Demirguc-Kunt, A. and Detragiache, E. 1998. Financial Liberalisation and Financial Fragility. IMF Working

Paper Series, WP/98/83. Washington, D.C.: International Monetary Fund

Djankov, S. and Pohl, G. 1998. The Restructuring of Large Firms in the Slovak Republic. Economics of

Transition, vol. 6, no.1, 67-86

Earl, J. and Tegdely, A. 1998. The Results of 'Mass Privatization' in Romania: a First Empirical Study.

Economics of Transition, vol. 6, no. 2, 313-332

EBRD 1998. Transition Report: Update 1998. London: European Bank for Reconstruction and Development

Elbirt, C. 1997. Albania Under the Shadows of the Pyramid Schemes. Transition, October 1997. Washington:

World Bank

Ellman, M.J. 1997. The Political Economy of Transformation. Oxford Review of Economic Policy, vol. 13, nr.

$2,23-32$

Federal Commission 1996. Federal Commission on Securities and the Capital Market of Russian Federation. Internet address: http://wwwfe.msk.rs/infomarket/fedcom/enews/law.html

Frank, R. and King, N. 1997. "Albania Moves Further Towards Collapse". Europe Section of the Wall Street Journal, March 6

Gomez, V. 1997. Albania: Pyramids in Ruins. Transition (published by the Open Media Research Institute), vol. 3 , no. 8,2

Gros. D. and Steinherr, A. 1995. Winds of Change. Economic Transition in Central and Eastern Europe. London and New York: Longman

Haderi, S., Papapanagos, H., Sanfey, P. and Talka, M. 1999. Inflation and Stabilisation in Albania. PostCommunist Economies, vol. 11, no. 1, 127-141

Hall, D. 1994. Albania and the Albanians. London: Pinter Publishers

Harris, F. 1997. Emergency Market. Business Central Europe, May issue, 19-20

Hashi, I. and Xhillari, L 1999. Privatisation and Transition in Albania. Post-Communist Economies, 99-125

Keynes, J.M. (1952 ed.) 'The Consequences to the Banks of the Collapse of Money Values' in Essays in Persuasion. London: Rupert Hart-Davis 
Kindleberger, C. (1978) Manias, Panics and Crashes: A History of Financial Crises. New York: Basic Books.

Laski, K. and Bhaduri, A. 1997. Lessons To Be Drawn From the Main Mistakes in the Transition Strategy. In:

S. Zecchnini (ed.) Lessons from the Transition. Dordrecht/Boston/London: Kluwer Academic Publishers

Lyle, R. 1997. Pyramid Schemes and the Limits of Conditionality. Transition (published by the World Bank), vol. 8 , no. 2,29

Mancellari, A. Papapanagos, H. and Sanfey, P. 1996. Job Creation and Temporary emigration: the Albanian experience. Economics of Transition, vol. 4, no. 2, 471-490

Marcincin, A. and Van Wijnbergen, S. 1997. The Impact of Czech Privatization methods on Enterprise Performance Incorporating Initial Selection-Bias Correction. Economics of Transition, vol. 5, no. 2, 289-304 McAdams, D. 1997. An Albanian Tragedy. Albania - CRISIS '97 News Centre. Internet address: http://www.albania.co.uk/crisis/daniel.html

McKinnon, R. 1992. Economy Taxation, Money and Credit in a Liberalizing Socialist. Economics of Planning, vol. 25, no. 1, 97-112

McNeilly, C. and Schiesser-Gachnang, D. 1998. Reducing Inflation: Lessons from Albania's Early Success. IMF Working Paper Series, WP/98/97. Washington, D.C.; International Monetary Fund Minsky, H. (1972) Financial Instability Revisited: The Economics of Disaster. In: Reappraisal of the Federal Reserve Discount Mechanism. Washington, D.C.: the Board of Governors of the Federal Reserve System. Minsky, H. (1977) The Financial Instability Hypothesis: An interpretation of Keynes and an Alternative to "Standard" Theory. Nebraska Journal of Economics and Business, vol 16, no. 1

Minsky, H. (1978) The Financial Instability Hypothesis: A Restatement. Thames Papers in Political Economy, autumn issue

Minsky, H. (1980) Capitalist Financial Processes and the Instability of Capitalism. Journal of Economic Issues, vol. XIV, no. 2

Minsky, H. (1982a) Financial Instability Revisited: the Economics of Disaster. In: Minsky, H. Inflation, Recession, and Economic Policy. Brighton: Harvester Wheatsheaf Minsky, H. (1982b) Can 'It' Happen Again? Essays on Instability and Finance. Armonk, NY: M.E. Sharpe. Nivat, A. 1997. Albania: Pointing Fingers After the Pyramid Collapse. Transition (published by the Open Media Research Institute), vol. 3, no. 10, 2

Nuti, D.M. 1996. Post-Communist Mutations. Emergo, winter 1996 
Nuti, D.M. and Portes, R. 1993. Economic Transformation in Central Europe: A Program Report. London: CEPR.

O'Connor, S. and Zeldes, S. 1992. "Ponzi Games". In: Harrowman, P., Milgate, M. and Eatwell, J. (ed.) 1992. The New Palgrave Dictionary of Money and Finance, vol. 3, 147-148. London and Basingstoke: The MacMillan Press

OECD 1996. Agricultural Policies, Markets and Trade in Transition Economies: Monitoring and Evaluation 1996. Paris: OECD

OMRI 1997. The Open Media Research Institute's Daily Digest on Internet

Pashko, G. 1993. Inflation in Albania. Communist Economies and Economic Transformation, vol. 5, no. 1, $115-126$

Reuter 1997. Various Press Communications. London: Reuter Press Agency

Sadiraj, K. 1999. Albania: Transition to a Market Economy. Tinbergen Institute Research Series, no. 202.

Amsterdam: University of Amsterdam

Schwartz, A. 1998. Market Failure and Corruption in the Czech Republic. Transition, vol. 8. no. 6, 4-5.

Schönfelder, B. 1996. The Doubtful Blessing of Capital Imports. Reflections on the Fragility of Croatian

Stabilisation. Communist Economies and Economic Transformation,vol. 8, no. 1, 67-73

Spicer, A. 1996. The Role of Institutions in Market Development: The Birth of the Russian Mutual Fund Industry. Paper presented at the Second Annual Workshop on the Economics of Transition to Market Systems, St. Petersburg, July 1996

Szekely, I. and Newbery, D. 1993. (eds) Hungary: An Economy in Transition. Cambridge: Cambridge University Press, 1993)

Tsang, S.-k. 1996. Against 'Big Bang'. Cambridge Journal of Economics, vol. 20, . 183-193.

Verdery, K. 1996. What Was Socialism, And What Comes Next? Princeton, NY: Princeton University Press. Wall Street Journal (1997: March 24). "Anarchy in Albania" in the Europe Section of the Wall Street Journal. Williamson, J. 1994. The Political Economy of Policy Reform. Washington, D.C.: Institute for International Economics

World Bank 1997. Albania - Informal Credit Markets. Tirana: World Bank Mission

Zecchini, S. 1997. Transition Approaches in Retrospect. In: Zecchnini, S. (ed.) Lessons from the Transition. Dordrecht/Boston/London: Kluwer Academic Publishers 
Tables

Table 1: Albanian Economic Indicators, 1989-1998

\begin{tabular}{|l|l|l|l|l|l|l|l|l|l|l|}
\hline Year & $\mathbf{1 9 8 9}$ & $\mathbf{1 9 9 0}$ & $\mathbf{1 9 9 1}$ & $\mathbf{1 9 9 2}$ & $\mathbf{1 9 9 3}$ & $\mathbf{1 9 9 4}$ & $\mathbf{1 9 9 5}$ & $\mathbf{1 9 9 6}$ & $\mathbf{1 9 9 7}$ & $\mathbf{1 9 9 8}$ \\
\hline GDP ( \% change) & -9.8 & -10.0 & -27.7 & -7.2 & 9.6 & 9.4 & 8.9 & 9.1 & -7.0 & 8.0 \\
\hline $\begin{array}{l}\text { Consumer prices } \\
(\% \text { change, average) }\end{array}$ & 0 & 0 & 35.5 & 226.0 & 85.0 & 22.6 & 7.8 & 12.7 & 32.1 & 20.6 \\
\hline $\begin{array}{l}\text { Exchange rate } \\
\text { (Lek/US\$, end-year) }\end{array}$ & 8.9 & 24.2 & 25.0 & 98.7 & 100.9 & 95.0 & 94.5 & 103.7 & 149.8 & 140.1 \\
\hline $\begin{array}{l}\text { Unemployment (\% labour } \\
\text { force, end-year) }\end{array}$ & 7.3 & 9.8 & 8.3 & 27.9 & 29.0 & 19.6 & 16.9 & 12.4 & 17 & n.a. \\
\hline $\begin{array}{l}\text { Budget deficit (\% GDP) } \\
\text { Foreign investment } \\
\text { (million US\$) }\end{array}$ & 0 & 0 & 0 & 32 & 45 & 60 & 70 & 95 & n.a. & n.a. \\
\hline
\end{tabular}

$\ddagger$ estimate. * Nominal GDP estimates are subject to a high degree of uncertainty. Annual changes in GDP should therefore be taken as indicative rather than precise.

Sources: OECD (1996:167) EBRD (1998:48), World Bank (1997), IMF (1996, unpublished), Albanian Ministry of Finance, Albanian Institute of Statistics. 
Table 2: Albanian Monetary and Fiscal Developments, 1990-1995

\begin{tabular}{|c|c|c|c|c|c|c|}
\hline Year & 1990 & 1991 & 1992 & 1993 & 1994 & 1995 \\
\hline \multicolumn{7}{|c|}{ money (\% change from previous period unless otherwise indicated) } \\
\hline broad money & 23 & 104 & 153 & 74 & 41 & 52 \\
\hline real broad money & 23 & - & -25 & 34 & 21 & 43 \\
\hline domestic credit & 22 & 100 & 113 & 54 & 31 & 24 \\
\hline broad money/GDP $(\%)^{1}$ & 37 & 69 & 54 & 40 & 38 & 48 \\
\hline \multicolumn{7}{|c|}{ general government (in \% of GDP) } \\
\hline Revenues & 47 & 32 & 24 & 26 & 25 & 24 \\
\hline expenditures $^{2}$ & 62 & 62 & 44 & 40 & 37 & 34 \\
\hline overall balance $^{3}$ & -4 & -44 & -20 & -14 & -12 & -10 \\
\hline domestic financing & 4 & 44 & 20 & 9 & 7 & 6 \\
\hline
\end{tabular}

Note: nominal GDP estimates are subject to a high degree of uncertainty. Ratios to GDP should therefore be taken as indicative rather than precise.

${ }^{1}$ end-year broad money divided by annual GDP. ${ }^{2}$ including on-lending. ${ }^{3}$ including net repayment of arrears Source: McNeilly \& Schiesser-Gachnang, 1998 
Table 3: Capital Inflows in Albania, 1990-1995 (in million US\$)

\begin{tabular}{|l|c|c|c|c|c|c|}
\hline year & $\mathbf{1 9 9 0}$ & $\mathbf{1 9 9 1}$ & $\mathbf{1 9 9 2}$ & $\mathbf{1 9 9 3}$ & $\mathbf{1 9 9 4}$ & $\mathbf{1 9 9 5}$ \\
\hline current non-IMF transfers & 15 & 107.6 & 148 & 230 & 265.7 & 300 \\
\hline of which: official transfers(non-IMF) & - & 80 & - & - & - & - \\
\hline \multicolumn{1}{|c|}{ private (worker's remittances) } & 15 & 27.6 & 150.2 & 274.7 & 379.1 & 384.7 \\
\hline IMF aid & - & - & 399 & 356 & 148 & 159 \\
\hline of which: grants & - & - & 343.8 & 302.2 & 134.2 & 55.7 \\
\hline \multicolumn{1}{|c|}{ medium/long term loans } & - & - & 55.2 & 53.8 & 13.8 & 103.3 \\
\hline foreign direct investment & 0 & 0 & 32 & 45 & 52.9 & 70 \\
\hline total registered capital inflows & 15.0 & 107.6 & 581.2 & 675.7 & 580.0 & 593.7 \\
\hline GDP & 1,130 & 1,139 & 710 & 1,228 & 1,984 & 2,422 \\
\hline registered capital inflows (\% GDP) & 13 & 9 & 82 & 55 & 29 & 25 \\
\hline
\end{tabular}

Note: Nominal GDP estimates are subject to a high degree of uncertainty. The trend in ratios to GDP should

therefore be taken as indicative rather than precise. Sources: IMF and World Bank data,EBRD (1998), McNeilly \&

Schiesser-Gachnang (1998:23), Haderi et al. (1999:135)

Table 4: Characteristics of Ponzi Schemes in Albania

\begin{tabular}{|c|c|c|c|c|c|c|}
\hline Name & Xhaferri & Populli & Sude & Vefa & Kamberri & Gjallica \\
\hline alleged status & \multicolumn{3}{|c|}{ Charity foundations } & \multicolumn{3}{|c|}{ companies } \\
\hline duration of operation (yrs.) & 3 & 1 & 4 & 5 & 3 & 3 \\
\hline $\begin{array}{l}\text { max. deposit accepted } \\
\text { (thousand Lek) }\end{array}$ & 3 & 10 & Unlimited & \multicolumn{3}{|c|}{ unlimited } \\
\hline denomination of deposit & \multicolumn{3}{|l|}{ Leks only } & \multicolumn{3}{|c|}{ Leks \& foreign currency } \\
\hline
\end{tabular}

Source: World Bank (1997) 
Table 5. Annual Interest Rates on Short-Term Deposits in the Formal and Informal Financial Sector in Albania, 1992-1995.

\begin{tabular}{|c|c|c|c|c|}
\hline year & formal sect & t for different & & informal sector \\
\hline deposit maturity & Quarterly & Six-Monthly & Annual & (15 days - 1 year) \\
\hline 1992 & 18 & 25 & 32 & 240 \\
\hline 1993 & 12 & 17 & 23 & 144 \\
\hline 1994 & 7 & 12 & 14.5 & 120 \\
\hline 1995 & 10 & 12 & 13.5 & 72 \\
\hline
\end{tabular}

* No evidence of the informal market accepting medium or long term-term deposits was found. The informal sector figures are averages over various maturity terms. Companies in this period offered $8-12$ per cent interest monthly for a six-month investment. Foundations offered a 50-100 per cent interest for three and six months deposits. Source: ACER, 1996.

Table 6: Albanian Trade Balance, 1991-1998

\begin{tabular}{|l|l|l|l|l|l|l|l|l|}
\hline Year & $\mathbf{1 9 9 1}$ & $\mathbf{1 9 9 2}$ & $\mathbf{1 9 9 3}$ & $\mathbf{1 9 9 4}$ & $\mathbf{1 9 9 5}$ & $\mathbf{1 9 9 6}$ & $\mathbf{1 9 9 7}$ & $\mathbf{1 9 9 8}$ \\
\hline exports & 73 & 70 & 112 & 141 & 205 & 229 & 167 & 206 \\
\hline imports & 281 & 524 & 602 & 601 & 679 & 921 & 685 & 840 \\
\hline trade balance & -208 & -454 & -490 & -460 & -474 & -692 & -518 & -634 \\
\hline
\end{tabular}

Source: IMF and World Bank data, EBRD (1998). 